\title{
EFFECTIVENESS OF GYPSUM APPLICATION AND PLOWING IN IMPROVING SEVERELY DETERIORATED CLAY SOIL CHARCTERISTICS AND WHEAT GROWTH AT QAROUN LAKE SHORE LINE, FAYOUM GOVERNORATE
}

Abdel-Nasser Amin Ahmed Abdel-Hafeez

Soil and Water Department, Faculty of Agriculture, Fayoum University

\begin{abstract}
Wide areas of severely deteriorated lands at Quaroun Lake shoreline have been left bare since a long time, although many attempts were made to cultivate some parts but all failed. A field experiment was carried out in a private field during the season 2014-2015 at the north of Fayoum Governorate (about $200 \mathrm{~m}$ from Quaroun Lake, Sinours District).Nine treatments were tested including the control, shallow and deep plowing ( 20 and $60 \mathrm{~cm}$ ), application of $50 \%$ and $100 \%$ of estimated gypsum requirements and their combinations. Remarkable decreases were found in the values of soil bulk density, ECe values, soluble cations and anions, soil paste $\mathrm{pH}$ and removal sodium efficiency ( RSE). Values of total porosity, hydraulic conductivity, field capacity, permanent wilting point, available water increased with soil deep plowing and gypsum application. Also, grain and straw yields of grown wheat crop were enhanced with soil deep plowing together with gypsum application and leaching with required amounts of water in comparison with those of the control treatment . Deep plowing with the application of $100 \%$ of estimated gypsum requirements resulted in the best improvement of both soil characteristics and plant growth among all other treatments. Results of the present experiment that was conducted in a private farm has actually encouraged farmers of the studied area to start land reclamation and cultivation of their lands that were left bare since a long time.
\end{abstract}

Key words: Salt-affected soils, Saline- sodic soil, gypsum, deep plowing , clay pan, wheat crop.

\section{INTRODUCTION}

Inadequate drainage is a serious problem as nearly $33 \%$ of the world irrigated lands is salt-affected especially in arid areas, ( Tanwar, 2003).Soils of the northern part of Fayoum basin, adjacent to Qaroun Lake, can be considered as a problematic area. They have heavy textural soil classes mostly with shallow depths of brackish ground water which is considered, the main cause of soil properties deterioration , (Mohamedin, 2002). Many agricultural soils have impermeable layers ( hard pan), from clay illuviation (clay pans), or cementation by either iron oxides, calcium carbonate, or silica, ( Brady and Weil, 2002). Many strategies including plowing, leaching, use of chemical amendments and organic fertilization achieve improvement in soil properties and help plant growth in these salt-affected soils.

Fayoum J. Agric. Res. \& Dev., Vol. 32, No.1, January, 2018 
Gypsum is the most low cost source of soluble calcium to replace exchangeable sodium from exchange complex and commonly used in the reclamation of saline-sodic and sodic soils, (Oster and Frenkel, 1980) and (Khan et.al., 1999). Rashid et.al. (2009) concluded that deep tillage and gypsum both in combination proved more effective in combating ill effects of salts and improving wheat yield in salt-affected soil. Also, Abdel-Fattah, (2012) found that application of gypsum combined with compost enhanced the reclamation process and caused more decreases in salinity as will as sodicity .Wide areas of lands at Quaroun Lake shore line have been left bare since a long time.

Objective of the present investigation was to study the effectiveness of gypsum and deep plowing and their combination in improving severely deteriorated heavy clay low permeable saline-sodic soil and their impact on wheat crop production at the north of Fayoum adjacent to Qaroun lake.

\section{Materials and Methods}

The experiment was carried out in a private farm at the north of Fayoum Governorate about $200 \mathrm{~m}$ from Quaroun lake, Sinours district which never received any previous gypsum applications. The morphological investigations showed that the studied soil have a blocked clay pan within the subsurface layer $(30-60 \mathrm{~cm})$ with a thickness of $10 \mathrm{~cm}$

( from 50 to $60 \mathrm{~cm}$ ) and suffering from salinity and sodicity, table (1).

Treatments were distributed in a randomized complete block design with four replicates each in $20 \mathrm{~m}^{2}$ ( 4 X $5 \mathrm{~m}$ ) plots.

Treatments were as follows:

$\mathrm{P}_{0} \mathrm{~g}_{0} \quad$ without plowing + zero gypsum

$\mathrm{P}_{0} \mathrm{~g}_{1} \quad$ without plowing $+50 \%$ of estimated gypsum requirements

P0 g2 without plowing $+100 \%$ of estimated gypsum requirements

$\mathrm{P}_{1} \mathrm{~g}_{0} \quad$ shallow plowing + zero gypsum

$\mathrm{P}_{1} \mathrm{~g}_{1} \quad$ shallow plowing $+50 \%$ of estimated gypsum requirements

$\mathrm{P}_{1} \mathrm{~g}_{2} \quad$ shallow plowing $+100 \%$ of estimated gypsum requirements

$\mathrm{P}_{2} \mathrm{~g}_{0} \quad$ deep plowing + zero gypsum

$\mathrm{P}_{2} \mathrm{~g}_{1} \quad$ deep plowing $+50 \%$ of estimated gypsum requirements

$\mathrm{P}_{2} \mathrm{~g}_{2} \quad$ deep plowing $+100 \%$ of estimated gypsum requirements

The leaching requirements were calculated to reduce soil initial ECe of (13.33 $\mathrm{dS} / \mathrm{m}$ ) to the mean of ECe values of the two layers , $0-30 \mathrm{~cm}$ and $30-60 \mathrm{~cm}$. according to Reeve equation (1975), as follows :

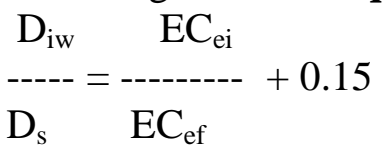

Fayoum J. Agric. Res. \& Dev., Vol. 32, No.1, January, 2018 
EFFECTIVENESS OF GYPSUM APPLICATION AND PLOWING..... 21

Table(1):Initial soil physical and chemical properties of the tested soil.

\begin{tabular}{|c|c|c|}
\hline \multirow[t]{3}{*}{ Soil property } & \multicolumn{2}{|c|}{ Value } \\
\hline & \multicolumn{2}{|c|}{ Soil depth, cm } \\
\hline & $0-30$ & $30-60$ \\
\hline \multicolumn{3}{|c|}{ Physical properties } \\
\hline \multirow{3}{*}{$\begin{array}{l}\text { Sand \% } \\
\text { Silt \% } \\
\text { Clay \% }\end{array}$} & 15.4 & 14.6 \\
\hline & 24.4 & 22.9 \\
\hline & 60.2 & 62.5 \\
\hline Texture class & Clay & Clay \\
\hline Bulk density $(\mathrm{Mg} / \mathrm{m} 3)$ & 1.35 & 1.4 \\
\hline Total porosity (\% on weight basis) & 49.06 & 53.90 \\
\hline Field capacity (\% on weight basis) & 43.33 & 43.60 \\
\hline Wilting point (\%on weight basis) & 24.60 & 28.80 \\
\hline Available water (\%on weight basis) & 18.73 & 14.80 \\
\hline Hydraulic conductivity $(\mathrm{cm} / \mathrm{h})$ & 0.35 & 0.20 \\
\hline \multicolumn{3}{|c|}{ Chemical properties } \\
\hline $\mathrm{pH}$ ( in soil paste) & 8.40 & 8.52 \\
\hline $\mathrm{ECe}(\mathrm{dS} / \mathrm{m})$ & 12.30 & 14.40 \\
\hline \multicolumn{3}{|c|}{ Soluble Cations, $\mathrm{mmole}^{+} / \mathrm{L}$} \\
\hline $\mathrm{Ca}^{++}$ & 22.40 & 23.40 \\
\hline $\mathrm{Mg}^{++}$ & 13.30 & 20.20 \\
\hline $\mathrm{Na}^{+}$ & 84.50 & 97.60 \\
\hline $\mathrm{K}^{+}$ & 1.80 & 1.70 \\
\hline \multicolumn{3}{|c|}{ Soluble anions , $\mathrm{mmole}^{-} / \mathrm{L}$} \\
\hline $\mathrm{CO}^{--}$ & 1.20 & 2.50 \\
\hline $\mathrm{HCO}^{-}$ & 4.50 & 4.60 \\
\hline $\mathrm{Cl}^{-}$ & 78.50 & 95 \\
\hline $\mathrm{SO}^{--}$ & 37.80 & 40.80 \\
\hline Exchangeable $\mathrm{Na}\left(\mathrm{cmole}^{+} / \mathrm{kg}\right)$ & 9.04 & 9.50 \\
\hline CEC, $\left(\right.$ cmole $\left.^{+} / \mathrm{kg}\right)$ & 41.02 & 41.60 \\
\hline ESP, $\%$ & 22.04 & 22.80 \\
\hline $\mathrm{CaCO}_{3},(\mathrm{~g} / \mathrm{kg})$ & 49.30 & 51.10 \\
\hline O.M, (g/kg) & 20.10 & 12.5 \\
\hline estimated gypsum requirements, $(\mathrm{t} / \mathrm{h})$ & \multicolumn{2}{|c|}{21.057} \\
\hline
\end{tabular}

Where $D_{\text {iw }}$ is the depth of leaching water in $\mathrm{cm}, \mathrm{D}_{\mathrm{s}}$ is the depth of leached soil in $\mathrm{cm}, \mathrm{EC}_{\mathrm{ei}}$ and $\mathrm{EC}_{\mathrm{ef}}$ are the electrical conductivity values of soil paste extract in $\mathrm{dS} / \mathrm{m}$ before and after leaching, respectively.

Calculated leaching water requirements $(49 \mathrm{~cm}$ ) was divided into 7 leachates; each was $7 \mathrm{~cm}$. All calculated leaching requirements were added with treatments before cultivation of wheat crop. Estimated EC of used irrigation water was $0.75 \mathrm{dS} / \mathrm{m}$, table (2).

Fayoum J. Agric. Res. \& Dev., Vol. 32, No.1, January, 2018 
Table(2) : Analysis of used irrigation water.

\begin{tabular}{|c|c|c|c|c|c|c|c|c|c|}
\hline $\mathbf{p H}$ & $\mathbf{E} \mathbf{C}_{\mathbf{w}}, \mathbf{d S} / \mathbf{m}$ & \multicolumn{3}{|c|}{ Soluble cations, $\mathbf{~ m m o l}^{+} / \mathbf{L}$} & \multicolumn{4}{|c|}{ Soluble anions, $\mathbf{~ m m o l} / \mathbf{L}$} & SAR \\
\cline { 3 - 9 } & & $\mathbf{C a}^{++}+\mathbf{M g}++$ & $\mathbf{N a}^{+}$ & $\mathbf{K}^{+}$ & $\mathbf{C O 3}^{-}$ & $\mathbf{H C O 3}$ & $\mathbf{C l}^{-}$ & $\mathbf{S O 4}^{--}$ & 1.66 \\
\hline 7.10 & 0.51 & 2.80 & 1.96 & 0.30 & - & 2.80 & 2.05 & 0.20 & \\
\hline
\end{tabular}

Wheat crop ( Triticum Sativum L.), Seds-1 Varity was planted in November 20, 2014. All cultural practices for grown plants has been conducted according to the Egyptian Ministry of Agriculture recommendations. After harvest, grains and straw yields were recorded.

At the end of experiment, soil samples were collected from the two layers $(0-30 \mathrm{~cm}$ and $30-60 \mathrm{~cm})$ to determine their physical and chemical properties. Statistical analysis was recorded using SPSS statistical program.

Soil physical properties were determined according to the methods described by Klute (1986).

Soil pH was measured in soil past ( Chapman and Pratt, 1961), soil organic matter was estimated according to Walkley and Black (1934) and $\mathrm{CaCO}_{3}$ using volumetric Calcimeter according to Allison and Moodie (1965). Electrical conductivity, soluble cations and soluble anions were measured in saturated soil paste extract ( USDA-NRCS, 2014). Cation exchange capacity was determined after Bower et.al. (1952), exchangeable sodium was extracted with buffered neutral $\mathrm{NH}_{4} \mathrm{OAC}$ solution and measured by flame photometer, and exchangeable sodium percentage (ESP) was calculated. (1954).

The gypsum requirements was estimated as described in USSL Staff

\section{Results and Discussions}

\section{1-Initial characteristics of the studied soil}

Data in table 1 indicated that soil of the studied field is saline- sodic heavy clay texture the two layers $(0-30 \mathrm{~cm}$ and $30-60 \mathrm{~cm})$, soil bulk density values increased with depth. However, values of total porosity, wilting point, available water and hydraulic conductivity decreased.

Results in table 2 showed that irrigation water used is non-saline $\left(\mathrm{EC}_{\mathrm{w}}<0.75\right.$ $\mathrm{dS} / \mathrm{m}$ ) according to the guidelines proposed by FAO (1992.

2-Some soil physical properties as influenced by the applied treatments

Actually, the soil bulk density plays a vital role in the further use of farm management, machinery and the crop growth and yield, Fayza Ahmed, (2004). 
EFFECTIVENESS OF GYPSUM APPLICATION AND PLOWING..... 23

Table(3) : Effect of applied treatments on the studied soil physical properties *

\begin{tabular}{|c|c|c|c|c|c|c|c|}
\hline Treatment & Depth, cm & $\begin{array}{c}\text { Bulk } \\
\text { density, }, \mathbf{M g} / \mathrm{m}^{3}\end{array}$ & $\begin{array}{c}\text { Total } \\
\text { porosity, \% on } \\
\text { weight basis }\end{array}$ & $\begin{array}{c}\text { Field } \\
\text { capacity, } \% \\
\text { on weight } \\
\text { basis } \\
\end{array}$ & $\begin{array}{c}\text { Wilting } \\
\text { point, \% on } \\
\text { weight basis }\end{array}$ & H.C** & $\begin{array}{c}\text { Available } \\
\text { water, } \% \text { on } \\
\text { weight basis }\end{array}$ \\
\hline \multirow{3}{*}{$\mathrm{P}_{0} \mathrm{~g}_{0}$} & $0-30$ & 1.34 & 50.53 & 44.63 & 25.74 & 0.38 & 18.89 \\
\hline & $30-60$ & 1.39 & 54.52 & 45.00 & 30.05 & 0.22 & 14.95 \\
\hline & Mean & 1.37 & 52.53 & 44.77 & 28.01 & 0.30 & 16.77 \\
\hline \multirow{3}{*}{$\mathrm{P}_{0} \mathrm{~g}_{1}$} & $0-30$ & 1.29 & 51.04 & 45.07 & 25.61 & 0.48 & 19.46 \\
\hline & $30-60$ & 1.38 & 55.07 & 45.36 & 29.98 & 0.32 & 15.38 \\
\hline & Mean & 1.34 & 53.06 & 45.22 & 27.80 & 0.40 & 17.42 \\
\hline \multirow{3}{*}{$\mathrm{P}_{0} \mathrm{~g}_{2}$} & $0-30$ & 1.26 & 52.05 & 45.97 & 26.30 & 0.61 & 19.67 \\
\hline & $30-60$ & 1.32 & 56.16 & 46.26 & 30.55 & 0.35 & 15.71 \\
\hline & Mean & 1.29 & 54.11 & 46.12 & 28.43 & 0.48 & 17.69 \\
\hline \multirow{3}{*}{$\mathrm{P}_{1} \mathrm{~g}_{0}$} & $0-30$ & 1.38 & 50.98 & 45.03 & 25.74 & 0.49 & 19.29 \\
\hline & $30-60$ & 1.33 & 55.01 & 45.31 & 30.06 & 0.29 & 15.25 \\
\hline & Mean & 1.36 & 53.00 & 45.17 & 27.90 & 0.39 & 17.27 \\
\hline \multirow{3}{*}{$P_{1} g_{1}$} & $0-30$ & 1.25 & 52.55 & 46.42 & 26.55 & 0.68 & 19.87 \\
\hline & $30-60$ & 1.33 & 65.70 & 46.71 & 31.00 & 0.40 & 15.71 \\
\hline & Mean & 1.29 & 59.13 & 46.57 & 28.78 & 0.54 & 17.79 \\
\hline \multirow{3}{*}{$\mathrm{P}_{1} \mathrm{~g}_{2}$} & $0-30$ & 1.30 & 51.60 & 45.50 & 25.61 & 0.76 & 19.89 \\
\hline & $30-60$ & 1.31 & 55.60 & 45.78 & 29.92 & 0.44 & 15.86 \\
\hline & Mean & 1.31 & 53.60 & 45.64 & 27.62 & 0.60 & 17.88 \\
\hline \multirow{3}{*}{$\mathrm{P}_{2} \mathrm{~g}_{0}$} & $0-30$ & 1.28 & 51.54 & 45.52 & 26.04 & 0.57 & 19.48 \\
\hline & $30-60$ & 1.36 & 55.61 & 45.81 & 30.41 & 0.33 & 15.40 \\
\hline & Mean & 1.32 & 53.58 & 45.67 & 28.23 & 0.45 & 17.44 \\
\hline \multirow{3}{*}{$\mathrm{P}_{2} \mathrm{~g}_{1}$} & $0-30$ & 1.23 & 54.08 & 47.75 & 27.11 & 0.84 & 20.64 \\
\hline & $30-60$ & 1.28 & 58.34 & 48.05 & 31.74 & 0.48 & 16.31 \\
\hline & Mean & 1.26 & 56.21 & 47.90 & 29.43 & 0.66 & 18.48 \\
\hline \multirow{3}{*}{$\mathrm{P}_{2} \mathrm{~g}_{2}$} & $0-30$ & 1.20 & 55.08 & 48.65 & 27.62 & 1.14 & 21.03 \\
\hline & $30-60$ & 1.25 & 59.43 & 48.95 & 29.66 & 1.10 & 19.29 \\
\hline & Mean & 1.23 & 57.26 & 48.80 & 28.64 & 1.12 & 20.16 \\
\hline
\end{tabular}

Each value in this table represents the mean of 4 replications*

** Hydraulic Conductivity

According to the above-mentioned, data (the table 3), the differences in soil physical properties may be referred to application of gypsum and deep plowing. The application of gypsum and deep plowing resulted in considerable decreases in the bulk density values of the studied soil, in agreement with the results obtained by Webster and Nyborg, (1986). The maximum mean decrease percentages of bulk density as calculated on basis of values of the two soil layers were 8.03 and $10.22 \%$ for deep plowing $+50 \%$ of gypsum requirements and deep plowing with $100 \%$ gypsum requirements , respectively, compared to the control treatment. Generally, the above mentioned results agree with those reported by Azhar et.al., (2001) and Prammanee et.al. (2007). Deep plowing and gypsum application and their combination increased soil total porosity values in comparison to the control treatment ( no plowing and no gypsum application).

Such effects has been observed in both surface and subsurface layers with the treatment (deep plowing $+100 \%$ gypsum requirements).Also, it could be concluded from Table (3) that, field capacity, wilting point and available water were increased for the two layers $(0-30 \mathrm{~cm})$ and $(30-60 \mathrm{~cm})$ as a result of using applied treatment. The greatest increase was found with treatment (deep plowing $+100 \%$

Fayoum J. Agric. Res. \& Dev., Vol. 32, No.1, January, 2018 
gypsum requirements). Soil hydraulic conductivity was increased by gypsum application and deep plowing. The greatest hydraulic conductivity values were obtained for treatment $\mathrm{p}_{2} \mathrm{~g}_{2}$ through the two tested soil layers. Hydraulic conductivity is especially sensitive to low electrolyte concentration. Thus, mixing gypsum into the soil can potentially increase hydraulic conductivity values, (Oster and Frenkel, 1980; Oster,1982 and Oad et.al., 2001a).

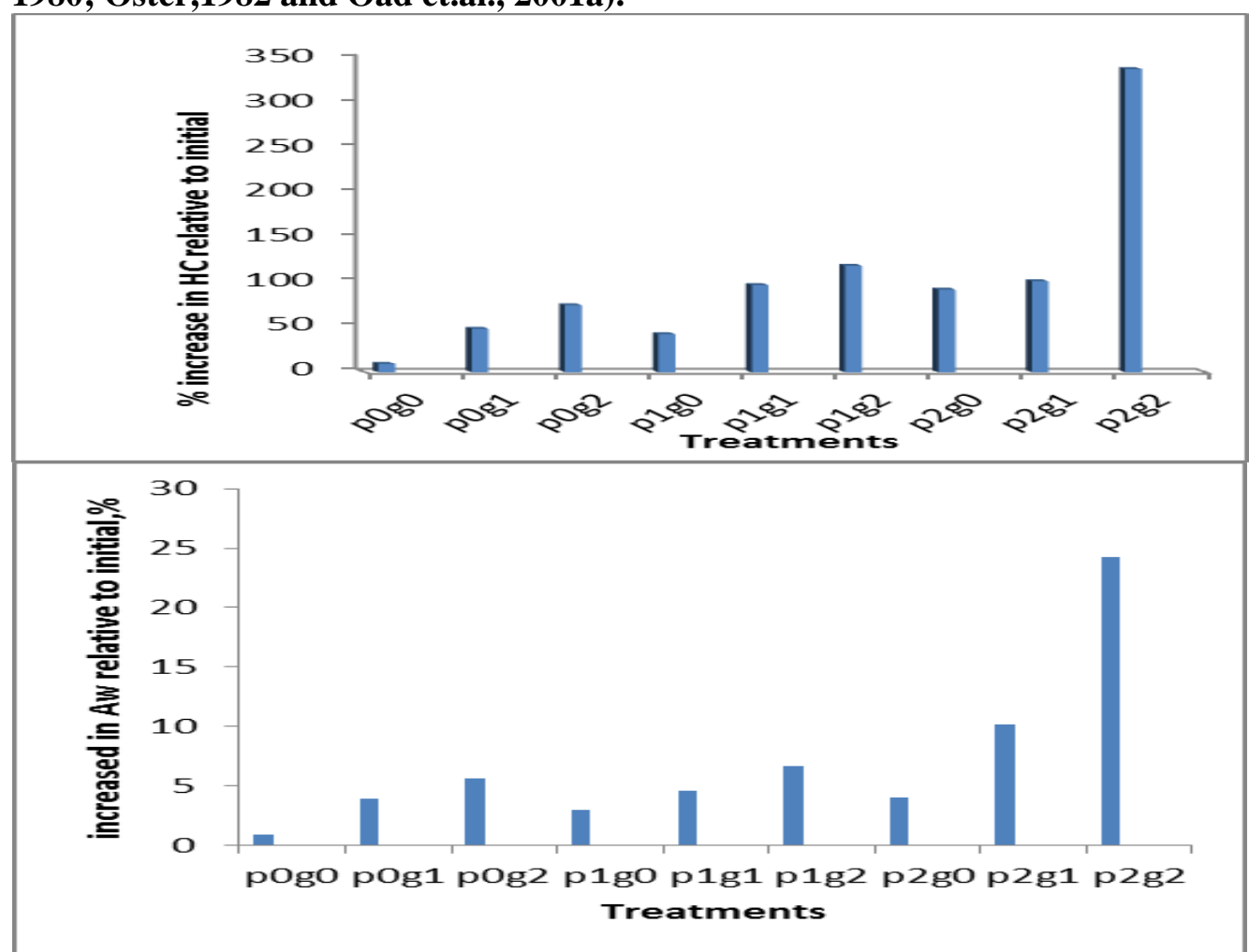

Figure (1): percent change in available water (AW) and hydraulic conductivity

(HC) relative to initial at the end of experiment.

Figure (1) show the percent change in available water and hydraulic conductivity at the end of experiment. It could be concluded that the available water values relative to initial expressed as mean percent increased from 0.93 $\%$ to $24.25 \%$ for the control and $\mathrm{p}_{2} \mathrm{~g}_{2}$ treatments, respectively. Hydraulic conductivity values relative to initial as percent increased from $9.29 \%$ to $337.86 \%$ for control and $\mathrm{p}_{2} \mathrm{~g}_{2}$ treatments ,respectively, at the end of experiment. The greatest increases were observed with $\mathrm{p}_{2} \mathrm{~g}_{2}$ treatment .

3-Some soil chemical properties as influenced by the applied treatments

Data presented in Table (4), indicated the reduction in soil $\mathrm{pH}$ due to soil deep plowing and gypsum application.

Fayoum J. Agric. Res. \& Dev., Vol. 32, No.1, January, 2018 
EFFECTIVENESS OF GYPSUM APPLICATION AND PLOWING..... 25

Table(4) : Effect of applied treatments on soil pH, ECe, solube cations and soluble Anions values in the tested soil.

\begin{tabular}{|c|c|c|c|c|c|c|c|c|c|c|c|}
\hline \multirow{2}{*}{ Treatment } & \multirow{2}{*}{$\begin{array}{c}\text { Soil } \\
\text { depth, } \mathrm{cm}\end{array}$} & \multirow{2}{*}{$\begin{array}{c}\text { pH } \\
\text { In soil } \\
\text { paste }\end{array}$} & \multirow{2}{*}{$\begin{array}{c}\text { ECe } \\
\mathrm{dS} / \mathrm{m}\end{array}$} & \multicolumn{4}{|c|}{$\begin{array}{l}\text { Soluble cations, mmole+/L, } \\
\text { in soil paste extract }\end{array}$} & \multicolumn{4}{|c|}{$\begin{array}{c}\text { Soluble anions, } \\
\text { mmole-/L, in soil paste extract }\end{array}$} \\
\hline & & & & $\mathrm{Ca}^{++}$ & $\mathrm{Mg}^{++}$ & $\mathrm{Na}^{+}$ & $\mathbf{K}^{+}$ & $\mathrm{CO3}^{--}$ & $\mathrm{HCO3}^{-}$ & $\mathrm{Cl}^{-}$ & SO4 \\
\hline \multirow{3}{*}{$\mathrm{P}_{0} \mathrm{~g}_{0}$} & $0-30$ & 8.23 & 9.84 & 18.14 & 10.77 & 68.45 & 1.46 & 0.97 & 3.65 & 63.59 & 30.61 \\
\hline & $30-60$ & 8.34 & 11.52 & 18.25 & 16.36 & 79.06 & 1.37 & 2.03 & 3.73 & 76.95 & 33.03 \\
\hline & & Mean & 10.68 & \begin{tabular}{|l|}
18.20 \\
\end{tabular} & 13.57 & 73.76 & 1.42 & 1.50 & 3.69 & 70.27 & 31.82 \\
\hline \multirow{3}{*}{$\mathrm{P}_{0} \mathrm{~g}_{1}$} & $0-30$ & 8.22 & 8.80 & 16.15 & 9.59 & 60.96 & 1.30 & 0.86 & 3.25 & 56.63 & 27.26 \\
\hline & $30-60$ & 8.33 & 10.30 & 16.34 & 14.65 & 70.78 & 1.23 & 1.80 & 3.30 & 68.49 & 29.41 \\
\hline & \multicolumn{2}{|c|}{ Mean } & 9.55 & 16.25 & 12.12 & 65.87 & 1.27 & 1.33 & 3.28 & 62.56 & 28.34 \\
\hline \multirow{3}{*}{$\mathrm{P}_{0} \mathrm{~g}_{2}$} & $0-30$ & 8.19 & 8.30 & 17.10 & 10.16 & 54.36 & 1.38 & 0.81 & 3.14 & 53.41 & 25.64 \\
\hline & $30-60$ & 8.30 & 9.70 & 15.39 & 13.80 & 66.66 & 1.15 & 1.70 & 3.13 & 64.91 & 27.26 \\
\hline & \multicolumn{2}{|c|}{ Mean } & 9.00 & 16.25 & 11.98 & 60.51 & 1.27 & 1.26 & 3.14 & 59.16 & 26.45 \\
\hline \multirow{3}{*}{$\mathrm{P}_{1} \mathrm{~g}_{0}$} & $0-30$ & 8.14 & 7.80 & 14.32 & 8.50 & 54.03 & 1.15 & 0.77 & 2.88 & 50.19 & 24.16 \\
\hline & $30-60$ & 8.26 & 9.20 & 14.59 & 13.08 & 63.23 & 1.10 & 1.61 & 2.96 & 61.17 & 26.26 \\
\hline & \multicolumn{2}{|c|}{ Mean } & 8.50 & 14.46 & 10.79 & 58.63 & 1.13 & 1.19 & 2.92 & 55.68 & 25.21 \\
\hline \multirow{3}{*}{$\mathrm{P}_{1} \mathrm{~g}_{1}$} & $0-30$ & 8.09 & 7.40 & 13.58 & 8.07 & 51.26 & 1.09 & 0.73 . & 2.73 & 47.62 & 23.65 \\
\hline & $30-60$ & 8.22 & 8.60 & 13.64 & 12.23 & 59.04 & 1.09 & 1.51 & 2.77 & 57.18 & 24.54 \\
\hline & \multicolumn{2}{|c|}{ Mean } & 8.00 & 13.61 & 10.15 & 55.15 & 1.09 & 1.67 & 2.75 & 52.40 & 24.10 \\
\hline \multirow{3}{*}{$\mathrm{P}_{1} \mathrm{~g}_{2}$} & $0-30$ & 8.06 & 6.90 & 13.66 & 8.11 & 51.54 & 1.09 & 0.73 & 2.74 & 47.88 & 23.05 \\
\hline & $30-60$ & 8.17 & 8.10 & 14.27 & 12.32 & 59.54 & 1.04 & 1.52 & 2.80 & 57.95 & 24.90 \\
\hline & \multicolumn{2}{|c|}{ Mean } & 7.50 & \begin{tabular}{|l|}
13.97 \\
\end{tabular} & 10.22 & 55.54 & 1.07 & 1.13 & 2.77 & 52.92 & 23.98 \\
\hline \multirow{3}{*}{$\mathrm{P}_{2} \mathrm{~g}_{0}$} & $0-30$ & 8.01 & 5.90 & 10.83 & 6.43 & 40.87 & 0.87 & 0.58 & 2.18 & 37.97 & 18.27 \\
\hline & $30-60$ & 8.10 & 6.90 & 10.95 & 9.81 & 47.42 & 0.82 & 1.21 & 2.22 & 45.87 & 19.70 \\
\hline & \multicolumn{2}{|c|}{ Mean } & 6.40 & 10.89 & 8.12 & 44.15 & 0.85 & 0.90 & 2.20 & 41.92 & 18.99 \\
\hline \multirow{3}{*}{$\mathrm{P}_{2} \mathrm{~g}_{1}$} & $0-30$ & 7.98 & 4.92 & 10.08 & 5.98 & 38.03 & 0.81 & 0.54 & 2.03 & 35.33 & 17.00 \\
\hline & $30-60$ & 8.09 & 5.76 & 10.53 & 9.09 & 43.92 & 0.76 & 1.12 & 2.07 & 42.75 & 18.36 \\
\hline & \multicolumn{2}{|c|}{ Mean } & 5.34 & 10.31 & 7.54 & 40.98 & 0.79 & 0.83 & 2.05 & 39.04 & 17.68 \\
\hline \multirow{3}{*}{$\mathrm{P}_{2} \mathrm{~g}_{2}$} & $0-30$ & 7.56 & 3.69 & 6.72 & 3.99 & 25.35 & 0.54 & 0.30 & 1.35 & 42.85 & 11.40 \\
\hline & $30-60$ & 7.70 & 4.32 & 7.02 & 6.06 & 29.28 & 0.51 & 0.75 & 1.38 & 28.50 & 12.24 \\
\hline & \multicolumn{2}{|c|}{ Mean } & 4.01 & 6.87 & 5.03 & 27.32 & 0.53 & 0.53 & 1.37 & 35.68 & 11.82 \\
\hline
\end{tabular}

The greatest decrease in soil $\mathrm{pH}$ was observed in deep plowing plots with the application of $100 \%$ gypsum requirement of soil, Values of soil ECe were considerably decreased within the two layers $(0-30)$ and $(30-60 \mathrm{~cm})$, from 9.84 to $3.69 \mathrm{dS} / \mathrm{m}$ and from 11.32 to $4.32 \mathrm{dS} / \mathrm{m}$ in soil surface and subsurface layers, respectively.

It is clear from table (4) that soluble cations and anions were considerably decreased in both surface and subsurface layers as a result of treatments, the greatest decrease was observed with deep plowing and the application of $100 \%$ of estimated gypsum requirements of soil.

Fayoum J. Agric. Res. \& Dev., Vol. 32, No.1, January, 2018 
Abdel-Nasser Amin Ahmed Abdel-Hafeez

Table(5): Values of CEC, ESP, OM and $\mathrm{CaCO}$ equivalent of the tested soil

\begin{tabular}{|c|c|c|c|c|c|c|}
\hline Treatment & Soil depth, cm & $\begin{array}{c}\text { CEC } \\
\text { Cmole+/kg }\end{array}$ & $\begin{array}{l}\text { Exch. Na, } \\
\text { cmole+/kg }\end{array}$ & ESP & $\begin{array}{l}\text { O.M } \\
\text { g/kg }\end{array}$ & $\begin{array}{c}\mathrm{CaCO3} \\
\mathrm{g} / \mathrm{kg}\end{array}$ \\
\hline \multirow{3}{*}{$\mathrm{P}_{0} \mathrm{~g}_{0}$} & $0-30$ & 41.43 & 8.22 & 19.84 & 20.5 & 48.31 \\
\hline & $30-60$ & 42.02 & 8.62 & 20.51 & 12.75 & 50.08 \\
\hline & Mean & 41.73 & 8.42 & 20.18 & 16.63 & 49.20 \\
\hline \multirow{3}{*}{$\mathrm{P}_{0} \mathrm{~g}_{1}$} & $0-30$ & 41.43 & 7.64 & 18.68 & 20.54 & 48.21 \\
\hline & $30-60$ & 42.43 & 8.22 & 19.37 & 12.78 & 49.97 \\
\hline & Mean & 41.93 & 7.93 & 19.03 & 16.66 & 49.09 \\
\hline \multirow{2}{*}{$\mathrm{P}_{0} \mathrm{~g}_{2}$} & $0-30$ & 41.51 & 6.99 & 16.84 & 20.58 & 48.12 \\
\hline & $30-60$ & 42.23 & 7.24 & 17.14 & 12.80 & 49.88 \\
\hline \multirow{4}{*}{$\mathrm{P}_{1} \mathrm{~g}_{0}$} & Mean & 41.87 & 7.12 & 16.99 & 16.69 & 49.00 \\
\hline & $0-30$ & 41.64 & 7.56 & 18.16 & 20.56 & 48.17 \\
\hline & $30-60$ & 42.36 & 7.84 & 18.51 & 12.79 & 49.80 \\
\hline & Mean & 42.00 & 7.70 & 18.34 & 16.68 & 48.98 \\
\hline \multirow{3}{*}{$P_{1} g_{1}$} & $0-30$ & 41.80 & 7.15 & 17.11 & 20.60 & 48.07 \\
\hline & $30-60$ & 42.44 & 7.41 & 17.45 & 12.81 & 49.60 \\
\hline & Mean & 42.17 & 7.28 & 17.28 & 16.71 & 48.84 \\
\hline \multirow{3}{*}{$\mathrm{P}_{1} \mathrm{~g}_{2}$} & $0-30$ & 41.93 & 6.17 & 14.72 & 20.64 & 47.90 \\
\hline & $30-60$ & 42.57 & 6.21 & 14.59 & 12.84 & 48.20 \\
\hline & Mean & 42.25 & 6.19 & 14.66 & 16.74 & 48.05 \\
\hline \multirow{3}{*}{$\mathrm{P}_{2} \mathrm{~g}_{0}$} & $0-30$ & 42.05 & 7.40 & 17.60 & 20.57 & 48.14 \\
\hline & $30-60$ & 42.71 & 7.59 & 17.77 & 12.79 & 47.90 \\
\hline & Mean & 42.38 & 7.50 & 17.69 & 16.68 & 48.02 \\
\hline \multirow{3}{*}{$\mathrm{P}_{2} \mathrm{~g}_{1}$} & $0-30$ & 42.25 & 5.75 & 13.60 & 21.11 & 47.14 \\
\hline & $30-60$ & 42.85 & 5.86 & 13.68 & 13.13 & 46.56 \\
\hline & Mean & 42.55 & 5.81 & 13.64 & 17.12 & 46.85 \\
\hline \multirow{3}{*}{$\mathrm{P}_{2} \mathrm{~g}_{2}$} & $0-30$ & 42.66 & 3.76 & 8.81 & 22.11 & 4637 \\
\hline & $30-60$ & 43.26 & 3.90 & 9.02 & 13.75 & 45.90 \\
\hline & Mean & 42.96 & 3.83 & 8.92 & 17.93 & 46.14 \\
\hline
\end{tabular}

Results of exchangeable sodium in $\mathrm{mmmol}^{+} / \mathrm{kg}$ soil and ESP remarkable reductions due to all treatments in comparison with the through surface and subsurface soil layers. ESP values decreased from $19.84 \%$ to $8.81 \%$ and from $20.51 \%$ to $9.02 \%$ within soil layers $(0-30 \mathrm{~cm})$ and $(30-60 \mathrm{~cm})$, respectively. Slight increases in O.M were observed after harvesting wheat crop as a result of applied treatment. The greatest increase was found with treatment $\mathrm{P}_{2} \mathrm{~g}_{2}$. It could be concluded from data presented in Table (5) that the percentage of $\mathrm{CaCO} 3$ content was decreased at the end of experiment from $48.31 \mathrm{~g} / \mathrm{kg}$ to $44.37 \mathrm{~g} / \mathrm{kg}$ and from $50.08 \mathrm{~g} / \mathrm{kg}$ soil to $45.90 \mathrm{~g} / \mathrm{kg}$ soil for surface and subsurface layers, respectively. This could be attributed to subsequent leaching of soil with migration water.

Fayoum J. Agric. Res. \& Dev., Vol. 32, No.1, January, 2018 
EFFECTIVENESS OF GYPSUM APPLICATION AND PLOWING..... 27

Table(6) : Percent change in ESP after treatments of the tested soil.

\begin{tabular}{|c|c|c|c|c|}
\hline Treatment & Depth,cm & ESP & \multirow[t]{3}{*}{ Reduced* ESP, \% $^{*}$} & \multirow[t]{3}{*}{$\mathbf{R S E}^{* *}$} \\
\hline \multirow[t]{2}{*}{ Initial } & $0-30$ & 22.04 & & \\
\hline & $30-60$ & 22.80 & & \\
\hline \multirow[t]{3}{*}{$\mathrm{P}_{0} \mathrm{~g}_{0}$} & $0-30$ & & 2.20 & 9.98 \\
\hline & $30-60$ & & 2.29 & 10.04 \\
\hline & Mean & & 2.25 & 10.01 \\
\hline \multirow[t]{3}{*}{$\mathrm{P}_{0} \mathrm{~g}_{1}$} & $0-30$ & & 3.36 & 15.25 \\
\hline & $30-60$ & & 3.43 & 15.04 \\
\hline & Mean & & 3.40 & 15.15 \\
\hline \multirow[t]{3}{*}{$\mathrm{P}_{0} \mathrm{~g}_{2}$} & $0-30$ & & 5.20 & 23.59 \\
\hline & $30-60$ & & 5.66 & 24.82 \\
\hline & Mean & & 5.43 & 24.21 \\
\hline \multirow[t]{3}{*}{$\mathrm{P}_{1} \mathrm{~g}_{0}$} & $0-30$ & & 3.88 & 17.60 \\
\hline & $30-60$ & & 4.29 & 18.82 \\
\hline & Mean & & 4.09 & 18.21 \\
\hline \multirow[t]{3}{*}{$\mathrm{P}_{1} \mathrm{~g}_{1}$} & $0-30$ & & 4.93 & 22.37 \\
\hline & $30-60$ & & 5.35 & 23.46 \\
\hline & Mean & & 5.14 & 22.92 \\
\hline \multirow[t]{3}{*}{$\mathrm{P}_{1} \mathrm{~g}_{2}$} & $0-30$ & & 7.32 & 33.21 \\
\hline & $30-60$ & & 8.21 & 36.01 \\
\hline & Mean & & 7.77 & 34.61 \\
\hline \multirow[t]{3}{*}{$\mathrm{P}_{2} \mathrm{~g}_{0}$} & $0-30$ & & 4.44 & 20.15 \\
\hline & $30-60$ & & 5.03 & 22.06 \\
\hline & Mean & & 4.74 & 21.11 \\
\hline \multirow[t]{3}{*}{$\mathrm{P}_{2} \mathrm{~g}_{1}$} & $0-30$ & & 8.44 & 38.29 \\
\hline & $30-60$ & & 9.21 & 40.39 \\
\hline & Mean & & 8.83 & 39.34 \\
\hline \multirow[t]{3}{*}{$\mathrm{P}_{2} \mathrm{~g}_{2}$} & $0-30$ & & 13.23 & 60.03 \\
\hline & $30-60$ & & 13.78 & 60.44 \\
\hline & Mean & & 13.51 & 60.24 \\
\hline
\end{tabular}

${ }^{*}$ Reduced ESP, \% $=$ ESP $_{\mathbf{i}}-\mathbf{E S P}_{\mathbf{f}}$

** RSE = Removal sodium efficiency in percentage of $\mathrm{Na}$ - removed from soil at the end of experiment was calculated according to Mahdy , (2011) as follows:

$\mathbf{R S E}=\mathbf{E S P}_{\mathrm{i}}-\mathbf{E S P}_{\mathrm{f}} / \mathrm{ESP}_{\mathrm{i} \text { x }} 100$

Data presented in Table (6) and figure (2) show percent change in ESP after applying treatments of the studied soil. The greatest reduction in ESP values was found with treatment $\mathrm{P}_{2} \mathrm{~g}_{2}, \mathrm{RSE}$ values greatly increased from about $9.98 \%$ with the control (no deep plowing and no gypsum ) to $60.24 \%$ with the treatment ( deep plowing $+100 \%$ of estimated gypsum requirement.

Fayoum J. Agric. Res. \& Dev., Vol. 32, No.1, January, 2018 


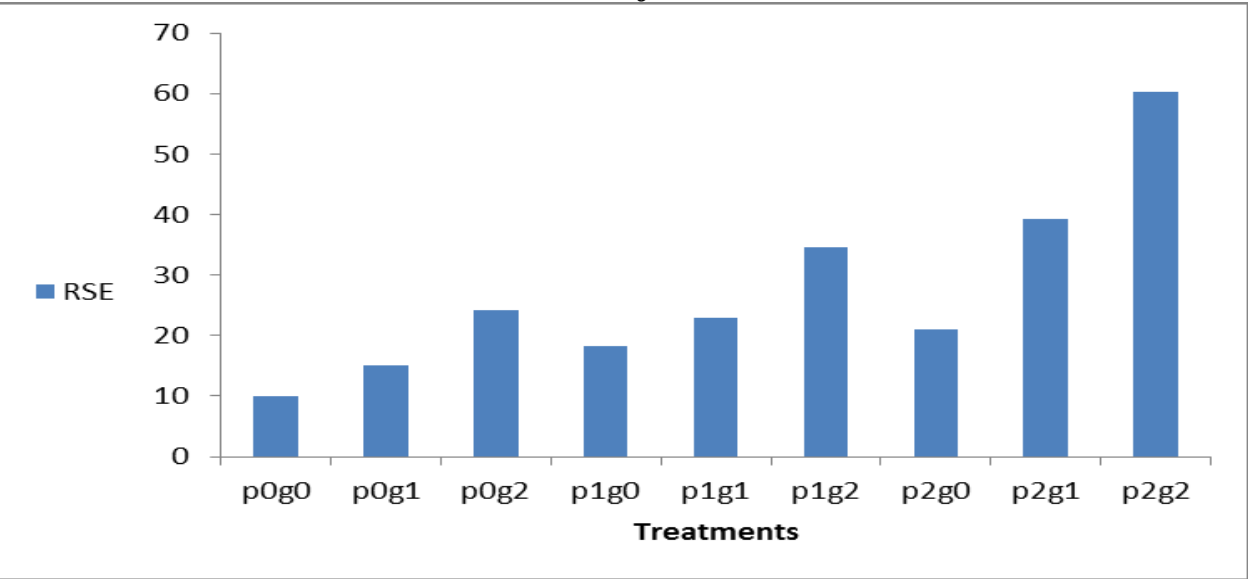

Figure (2): Removal sodium efficiency (RSE) in percentage of $\mathrm{Na}-$ removed from soil at the end of experiment.

\section{4- Some plant parameters as influenced by the applied treatments}

Table (7) indicate values of grain and straw yield of wheat plant as affected by the applied treatment.

Table (7): Effect of applied treatments on grain and straw yields of wheat

crop.

\begin{tabular}{|c|c|c|}
\hline \multirow{2}{*}{ Treatment } & \multicolumn{3}{|c|}{ Wheat yield (t/he) } \\
\cline { 2 - 3 } & grain & straw \\
\hline $\mathrm{P}_{0} \mathrm{~g}_{0}$ & $3.738 \mathrm{c}$ & $4.405 \mathrm{f}$ \\
\hline $\mathrm{P}_{0} \mathrm{~g}_{1}$ & $3.810 \mathrm{c}$ & $4.350 \mathrm{f}$ \\
\hline $\mathrm{P}_{0} \mathrm{~g}_{2}$ & $4.214 \mathrm{bc}$ & $5.320 \mathrm{ef}$ \\
\hline $\mathrm{P}_{1} \mathrm{~g}_{0}$ & $3.200 \mathrm{bc}$ & $4.200 \mathrm{def}$ \\
\hline $\mathrm{P}_{1} \mathrm{~g}_{1}$ & $4.917 \mathrm{abc}$ & $4.907 \mathrm{cde}$ \\
\hline $\mathrm{P}_{1} \mathrm{~g}_{2}$ & $5.476 \mathrm{abc}$ & $5.990 \mathrm{bcd}$ \\
\hline $\mathrm{P}_{2} \mathrm{~g}_{0}$ & $3.512 \mathrm{abc}$ & $4.881 \mathrm{abc}$ \\
\hline $\mathrm{P}_{2} \mathrm{~g}_{1}$ & $6.238 \mathrm{ab}$ & $6.238 \mathrm{eb}$ \\
\hline $\mathrm{P}_{2} \mathrm{~g}_{2}$ & $7.024 \mathrm{a}$ & $6.500 \mathrm{a}$ \\
\hline
\end{tabular}

It could be observed from statistical analysis of data presented in Table (7) that there are significant differences $(P \leq 0.05)$ among treatments concerning grain and straw yields of wheat. The greatest increase in grain and straw yields of wheat plants were associated with treatment $\mathrm{p}_{2} \mathrm{~g}_{2}$, this could be due to the increase of available water $\%$ and the decrease of both soil salinity and sodicity stress through plant growth stages as a result of soil deep plowing, gypsum application and leaching with water.

Fayoum J. Agric. Res. \& Dev., Vol. 32, No.1, January, 2018 


\section{References}

Abdel-Fattah, M.K.,2012. Role of gypsum and compost in reclaiming salinesodic soils. IOSR J. of Agric. veterinary Sci. Vol. 1, Issue 3 ( Sep. Oct. 2012), pp $30-38$.

Azhar, M.; M. Iqbal, M.A. Khan and M. Ashraf, 2001. Effects of tillage implements in combination with gypsum applications on the reclamation of saline-sodic soils. Int. J. Agri. Biol., Vol.3, No. 3.

Bower, C.A. ; R.F., Reitemeier and M., Fireman, 1952. Exchangeable cations Analysis of Saline and Alkali Soils. Soil Sci., $73: 251$.

Brady, N.C. and R.R., Weil, 2002. The Nature and Properties of Soils. $13^{\text {th }}$ ed. 960 pp., Prentice Hall. Upper Saddle River, N.J.

Chapman, H.D. and P.F.,Partt, 1961. Methods of Analysis for Soils, Plants and Water. Uni. Of California Agr. Sci., Brekeley.

FAO,1992. The use of saline waters for crop production. Rhodes, J.D.; A. Kandiah and R.M., Mashak, FAO Irrigation and Drainage Paper. 48. FAO, Rome.

Fayza Ahmed A. 2004. Improvement of soil properties through use of some amendments applications. Ms.c. Thesis, Fayoum Fac. Of Agric., Cairo University.

Khan, G.S.; M.I., kram and A.H., Ansari, 1999. Amelioration of Patchy ( Sparse) salinity / sodicity in irrigated plain of Pakistan ( A case study. Pak. J. Soil Sci., 16: 21-24.

Klute, A., 1986. Methods of Soil Analysis. Part-1: Physical and Mineralogical Methods.

( $2^{\text {nd }}$ ed.). Amer. Soci. Of Agro., Madison, Wisconsin, USA.

Mahdy, A.M., 2011. Comparative effects of different soil amendments on amelioration of saline-sodic soils. Soil and Water Res., b, 2011 (4) : $205-2016$.

Mohamedin, A.A.M., 2002. Tile drainage efficiency as affected by soil and hydrological properties at the north of El-Fayoum Governorate. Ph.D. Thesis, Fac. Of Agric. Ain Shams University.

Oad, F.C.; D.L., Oad; A. Soomro; N.L.Oad and Z.A., Abro, 2001a. Ameliorative effect of soil amendments and revalent field practices in saline - sodic soil. Pak. J. of Applied Sci. Vol. 1 (3) pp: 353-355.

Oster, J.D. and H. Frenkal, 1980. Chemistry of reclamation of sodic soil with gypsum and lime. Soil Sci. Soc. Amer. J., 44 (1) , 41 - 45.

Oster, J.D., 1982. Gypsum usage in irrigated agriculture. A review, Fertilizer Research $3: 73-89$.

Prammane, P.; S. Saensupo ; P. Weerathaworn and A. Sriwarome, 2007. Minimum tillage: ten years of experience. Sugarcan International, Junuary/February. Vol. 26, No. 1.

Fayoum J. Agric. Res. \& Dev., Vol. 32, No.1, January, 2018 
Abdel-Nasser Amin Ahmed Abdel-Hafeez

Qadir M. ; S. Schubert ; A. Ghafoor and G. Murtaza , 2001. Amelioration strategies for sodic soils. A review Land Degradation and development, $12: 357-386$.

Rashid, A., , R.U. Khan and S.K. Marwat,., 2009. Response of wheat to soil amendments with poor quality irrigation water in salt affected soil. World J. of Agricultural Sciences 5 (4) : 422-424.

Reeve, R.C., 1975. The relation of salinity to irrigation and drainage requirement. $3^{\text {rd }}$ Cong. On irrigation and drainage Tran. $5: 157-$ 187.

Richards, L.A., 1954. Diagnosis and improvement of saline and alkaline soils. USDA, Handb. 60. US. Gov. Print Office, Washington, DC.

Snedercor, G.W. and W.G., Cockran, 1980. "Statistical Methods" $\left(7^{\text {th }}\right.$ ed.) Iowa State University, Iowa, USA.

Tanwar, B.S., 2003. Soil Water Management for Irrigation. International Commission on Irrigation and Drainage (ICTD), New Delhi, India.

USDA-NRCS, 2014. Kellogg Soil Survey Laboratory Methods Manual. Soil survey Investigations Report No. 42, Version 5.

Walkley, A. and I. A. Black. 1934. An examination of Degtjareff method for determining soil organic matter and a proposed modification of the chromic acid titration method. Soil Sci. 37:29-37

Webster, G.R. and M., Nyborg, 1986. Effects and selected soil properties of two solontzic sols. Canadian Journal of Soil Sci. , $66: 455-470$.

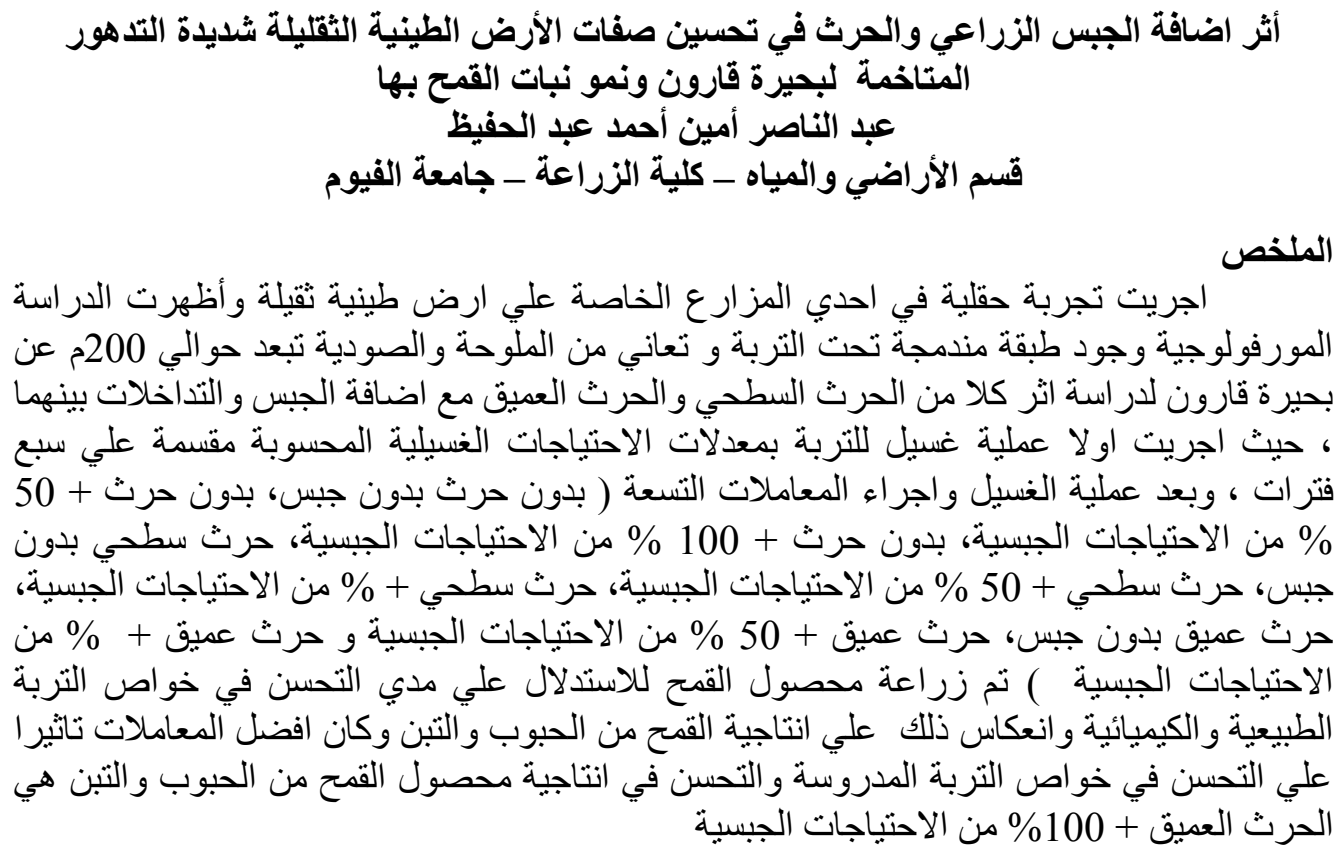

Fayoum J. Agric. Res. \& Dev., Vol. 32, No.1, January, 2018 